\title{
ANÁLISE DE DADOS PARA O MODELAMENTO DE VARIOGRAMAS
}

\author{
J.K. Yamamoto ${ }^{1}$ \\ R.P.Conde ${ }^{2}$
}

A obtenção de um variograma representativo é fundamental para aplicação satisfatória dos métodos geoestatísticos de estimação em avaliação de reservas. $O$ variograma é a ferramenta básica que descreve quantitativamente a variância espacial de uma variável regionalizada. O modelamento do variograma é feito a partir do variograma médio experimental. Contudo, quando se utiliza de programas de computador para modelamento de variogramas, estes geralmente não apresentam os variogramas parciais, mas tão somente o variograma médio experimental, que nem sempre é representativo do conjunto de dados devido a existência de valores anômalos. É justamente neste aspecto que este trabalho está sendo escrito, ou seja, fazendo uma análise crítica dos passos de cálculo dos variogramas experimentais, mostrando a necessidade de uma prévia análise estatística dos dados que permitirá relacionar os dados para obtenção de um variograma experimental representativo. pois freqüentemente, valores de teor em depósitos minerais apresentam valores anômalos, principalmente em depósitos de alta variabilidade natural como são os depósitos de ouro. Como a variância espacial é calculada como média dos desvios quadráticos, a presença de um único ou poucos valores anômalos pode distorcer completamente o nível de variância máxima dos variogramas. Se esses valores anômalos são retirados, o variograma médio é mais representativo dos variogramas parciais, pois estes apresentam-se com variabilidade máxima em torno da variância amostral dos dados. Esta análise crítica e, ao mesmo tempo, proposta metodológica de modelamento de variogramas são feitas com base nos valores de teores de ouro de uma jazida de ouro em lavra.

${ }^{1}$ Departamento de Geologia Econômica e Geofísica Aplicada, Instituto de Geociências, USP.

2Pós-graduação, Departamento de Geologia Econômica e Geofísica Aplicada, Instituto de Geociências, USP. 